University of Wollongong

Research Online

Faculty of Education - Papers (Archive) Faculty of Arts, Social Sciences \& Humanities

December 2002

\title{
Using on-line discussion to develop preservice teacher understanding of classroom management
}

Brian Ferry

University of Wollongong, bferry@uow.edu.au

J. Kiggins

University of Wollongong, jkiggins@uow.edu.au

G. Hoban

University of Wollongong, ghoban@uow.edu.au

Follow this and additional works at: https://ro.uow.edu.au/edupapers

Part of the Education Commons

\section{Recommended Citation}

Ferry, Brian; Kiggins, J.; and Hoban, G.: Using on-line discussion to develop preservice teacher understanding of classroom management 2002.

https://ro.uow.edu.au/edupapers/2

Research Online is the open access institutional repository for the University of Wollongong. For further information contact the UOW Library: research-pubs@uow.edu.au 


\title{
Using On-Line Discussion to Develop Preservice Teacher Understanding of Classroom Management.
}

\author{
By Brian Ferry, Julie Kiggins and Garry Hoban \\ Faculty of Education \\ University of Wollongong \\ Email: bferry@uow.edu.au
}

\begin{abstract}
This paper describes how a knowledge building community (KBC) of preservice teachers used an on-line discussion forum to develop knowledge about the role of the teacher in modern schools. It traces their initial use of the technology and follows the evolution of its use over a three-year period describing the role of the students and university lecturers in facilitating discussion. The paper then focuses on how members of the KBC used an on-line discussion forum to reflect on and share learning experiences as they developed classroom management strategies.
\end{abstract}

\section{INTRODUCTION}

Studies of learning in schools and universities show that knowledge is often presented in a fragmented and decontextualised way (Entwhistle, Entwhistle \& Tait, 1993). As a result the knowledge is not retrievable in real-life situations because there is no link to the situation in which it applies. Teacher education courses have been criticised for the same reasons (Ramsey, 2000) explaining why many researchers report that beginning teachers are unable to relate what they have studied at university to how it can be translated into effective classroom practice (MACQT, 1998).

Moreover, reviews of beginning teacher competencies over the past 80 years continually identify a number of key management skills that are inadequately developed. These include: student discipline, motivating students, dealing with individual differences, insufficient and/or inadequate resources, organisation of classwork, assessing student work, and relationships with parents (Koetsier \& Wubbels, 1995). The Ramsey (2000) review of teacher education in NSW supported these findings and asserted that preservice teachers do not understand how to manage the classroom so that it becomes an effective learning environment.

One way to address this deficiency is to re-think school-based practice teaching programs. Since 1999, Ferry, Cambourne and Kiggins have coordinated a team of researchers who have re-conceptualised the schoolbased practice teaching by planning, implementing and evaluating an alternative approach known as the 'Knowledge Building Community' or KBC (Ferry,
Kiggins, Hoban \& Lockyer, 2000.). The KBC consisted of a group of peers, lecturers and school-based teachers, who all play a role in supporting decisions and encouraging reflection.

Research about the KBC program has shown that a focus on the development of knowledge and skills in contexts that reflect the way that they are used in real life is an effective and powerful approach to teacher education. A critical aspect is the notion of the apprentice (or neophyte) observing a 'community of practice' (Lave \& Wagner, 1991). This process allows the neophyte to progressively piece together the culture of the group and to understand what it means to be a member. To facilitate the process we made use of an online discussion forum to create a dynamic learning community whose task was to build knowledge about the teaching profession.

This study emphasised sustained conversations and activities that were grounded in real life experience. Thus, the research focus is on how $\mathrm{KBC}$ members used an on-line discussion forum to reflect on and share learning experiences as they developed understandings of effective classroom management strategies.

\section{BACKGROUND}

When information comes to people via the Internet there are many benefits such as: direct access to a broader range of information; access to learning environments outside normal lecture and tutorial times; greater opportunity for experiencing a variety of instructional strategies including small group discussion and collaborative projects; and exposure to a forum for expressing and sharing ideas (Lockyer, Patterson \& Harper, 1999). Some researchers claim that education that is entirely based on such technology contributes toa loss of community (Besser and Bonn, 1996), but Romiszowski and Mason (1996) showed that technology does allow for genuine conveyance of human communication. This study contributes to this debate by focusing on the use used an on-line discussion forum to foster preservice teacher understanding of the role teachers take in managing the classroom. 


\section{A KNOWLEDGE COMMUNITY (KBC) EDUCATION \\ BUILDING IN TEACHER}

A 'knowledge building community' (KBC) is described by Berieter and Scardamalia (1993) as a group of people who investigate problems. Members work as groups and are engaged in progressive discourse in an iterative process of knowledge building. The Faculty of Education at the University of Wollongong wanted to use a KBC approach to respond to recurrent themes emerging from studies that sought to follow-up graduates of teacher education courses. One was that often students reported that they left university feeling under-prepared for life in classrooms and confused by what confronted them when they arrived at schools and became part of a team that managed the school (Ramsey, 2000). Schools reported that a majority of recent graduates were unaware of how school and classroom cultures operated - particularly how teachers worked in small problemsolving teams to manage the school (MACQT, 1998; Ramsey 2000).

The on-line discussion forum was designed to provide students with a communication tool to engage in informal processes of knowledge sharing and construction. We believed that such a forum supplements face-to-face teaching by providing discussion forums that are non-threatening. The forum also allows individuals to maintain links with their community of practice and to take advantage of the scaffolding that is provided by a dynamic social context - allowing for legitimate peripheral participation (Lave \& Wegner, 1991).

The literature claims that "professional socialisation is a complex and variable form of learning, highly collaborative in nature"(Weedman, 1998, p.1) and involves the transmission of social constructs, language, belief systems and symbolic lives that are unique to the profession (Schon, 1983). Brown and Duguid (1993) argue that this type of learning makes use of knowledge that must be 'stolen'. They contend that the most important knowledge is that which cannot be taught and students must find ways to 'steal' it from their educational environment.

The initial KBC course had two parts. The first part ran for five weeks and was designed to prepare students to work in a learning community and to understand how people work in teams to solve problems. During he second part of the KBC course students attended their host school for two days per week and attended university for one or two days per week. Whilst in schools they had two main roles. One was to be an effective teaching associate and the other was to be what we called 'an educational anthropologist'.
An educational anthropologist 'lives' within the school community and 'steals knowledge' (Brown \& Duguid, 1993) that helps them to understanding of the culture of their schools and of the actions of the children and teachers that they observe. Thus, they work with a number of teachers, school executive and allied professionals (e.g. counsellors, teacher aides, school executive, special support staff) who act as 'informants' about their profession and the culture of the school.

This study focuses on the second year of the KBC. These students completed the Year $1 \mathrm{KBC}$ program in 1999 and were developing many of the skills needed to be a successful teaching associate and educational anthropologist. Also they had developed basic planning skills and had some understanding of how teachers work with a team of professionals to manage safe, secure and productive learning environments.

The goal of the second year of $\mathrm{KBC}$ was for preservice teachers to develop the knowledge and skills needed to begin to effectively manage a safe, secure and productive learning environment. To help achieve this they spent 2 days per week in schools and 2 days at university focusing on problem-based tasks that are jointly constructed by the host school, university and the preservice teachers.

\section{PURPOSE OF STUDY}

The purposes of the study were:

1. To understand how members of the knowledge building community made use of an on-line discussion forum to developed their understanding of the role of primary school teachers - in particular effectively managing a safe, secure and productive learning environments;

2. To describe the role that the lecturers took in mediating on-line discussion among members of the knowledge-building community.

The following research questions were posed:

1. How did student use of an on-line discussion forum help them to develop an understanding of the role of primary teachers in effectively managing safe, secure and productive learning environments?

2. What were some of the limitations associated with the use of an on-line discussion forum?

3. What role did the lecturers play in mediating the on-line discussions?

\section{PARTICIPANTS}

This study, conducted in (2000), was limited to a group of 24 Year 2 primary education students enrolled in a $\mathrm{KBC}$ course in teacher education. The age of the 
students ranged from 18 years to 45 years and gender composition was three males and 21 females.

During the second week of the session all participants were taught to use an on-line discussion forum embedded in WebCT. Although WebCT could be accessed from home computers, we also allowed access to a group of five computers located in their university home-room or from any of the computers within the university computing laboratories. The purpose of the WebCT site was to create the discussion forum and data from the 945 entries made over a 12 week period that is used in this study.

\section{LIMITATIONS}

Knowledge building for the $\mathrm{KBC}$ involved three sources: the community of learners (i.e. preservice teachers, lecturers and teachers), school based learning and problem-based learning. The scope of this study is focused on how an asynchronous discussion forum is used as a means of synthesizing these sources of learning.

\section{METHODS}

The purpose of the first part of the study was to understand how members of the $\mathrm{KBC}$ made use of an on-line discussion forum to develop an understanding of the role of teachers in effectively managing safe, secure and productive learning environments. Data were gathered from two sources: text downloaded from the asynchronous forum and interviews with lecturers. Students gave us permission to download their messages and were aware that others would be able to read their messages. They wished to be identified as they were wanted to show others how they used the discussion space. Data pertaining to the lecturers' role in mediating on-line discussion and verification came from postsession interviews with lecturers and analysis of downloaded text from the forum.

\section{RESULTS AND DISCUSSION}

The results are organised under the headings of lecturer input, classroom experience, reflecting and connecting to illustrate how the inputs from various sources helped in building community knowledge about classroom management. The ways in which the on-line discussion forum was used and the roles the lecturers played in facilitating on-line discussion are also described in this section.

\section{Lecturer input}

$\mathrm{KBC}$ students had the option of attending lecturers that were relevant to their school experiences during the session. And they attend a total of 6 from the 80 available to mainstream students. They were careful to select only those that would add to their current needs, as illustrated by the entries below.

Article No. 65 posted by $J$ on Wed, Mar. 22, 2000, 14:14

I also learnt a lot from the lecture this week on difficult behaviours. I thought it was fantastic to hear the real life experiences of the lecturer. Article No. 93: posted by $L$ on Sun, Mar. 26, 2000, 07:53

For myself, this lecture was one of the best and most useful, if not THE best...

Later $\mathrm{L}$ reflected on the readings she had done and made following comments:

Glasser's points of psychological needs of children (us all): Love/belonging, Power Control (power to, rather than power over), Freedom Independence, Fun/Excitement. We have to do something to meet these needs in the classroom to decreased behaviour problems.

Later the lecturer provided KBC students with the opportunity to view a video on classroom management produced by Bill Rogers, a world-renown expert. Their comments follow:

Article No. 172: posted by $K$ on Tue, Apr. 4, 2000, 11:48

...I must agree with $\mathrm{J}$ that although he seemed a bit of a clown.. the underlying meaning was quite beneficial to my learning... It reminded me of last year's teaching.. there was one boy who I'm sure always mucked up just to test my management strategies. Which back then were non existent. Having, listened to D's lectures and from watching this video, I have thought of some things I could have tried on this young man.

At this stage the KBC students were starting to focus in on their school experience. They were making connections to pas t experiences and planning for their next experience in schools which was about to commence. Also one of lecturers, Julie was encouraging to follow up and apply what they had learnt at university.

\section{Classroom Experience}

This section looks at how the classroom experience linked to their university experience. The discussion shows how the students looked for connections to their university work but at the same time they made use of other sources of learning such as their mentor teachers, peers and facilitators. It shows that many were naïve about how teachers managed classrooms but at the same time they were prepared to question and challenge some of the strategies they observed.

Article No. 197:posted by $F$ on Wed, Apr. 5, 2000, 20:22 
I watch a lesson today by a male teacher and he used a lot of Bill Roger's ideas and guess what...they worked. ...It all made sense.

Article No. 203: posted by $L$ on Wed, April. 5, 2000, 21:24

I thought you might like to know about what my mentor teacher told us about "classroom rules" she explained that children in her class, have sometimes not been able to effectively use the rules up on the wall as they cannot read them yet! She suggests using picture clues on the walls.

Facilitator input- Article No. 214: posted by J on Thursday, April $6^{\text {th }}, 2000,17: 04$

Lisa, Thanks for sharing that advice about the rules that is a really great management strategy, ie using pictures as clues to reinforce the class rules. Did any one else pick up anything different? Julie

Article No. 405: posted by $K$ on Tue, Apr. 18, 2000, 12:02

I actually have found it interesting in the $\mathrm{K} / 1$ classroom I'm in, that there doesn't seem to be ANY sign of class rules....The teacher seems to just discipline right then and there as she teaches...

Article No. 292: posted by JT on Tue, Apr. 11, 2000, 12:45

Hi Everyone! One thing I noticed after my first day at school was the amount of bribing the teachers do to get the students to behave. My teacher has a points system. The students are rewarded for good behaviour by receiving 10 points. At the end of the term the students with the most points receive a prize.

Anyway the following day I had to take a music lesson. I couldn't believe how disruptive the students actually were.. . That's when I realised that bribery works....

Sure prizes and stickers may get the students to be quiet, but it doesn't mean they will learn anything. Just because the students are silent does not mean they are hearing what you are saying.

Facilitator input - Article No. 330: posted by $\mathrm{Br}$ on Fri, Apr. 14, 2000, 17:11

$\mathrm{J}$ do believe that classroom management it isn't as simple as bribery. Do would others like to comment?. Brian

There were 195 entries relating to classroom management and coding of these data showed that as time in the classroom increased student discussion move from a focus more on daily class-based experiences to the more difficult cases that times appeared to be intractable. Management problems were shared and successful outcomes celebrated on line and those problems that were not solved were shared so at least their learning community could be supportive.

\section{Reflecting and connecting}

This section provides examples of student reflection and it also illustrates how they were connecting the various source of knowledge together to generate their own understanding of classroom management. They have used a wide variety of sources including recommended texts, mentor teachers and peers.

Article No. 425: posted by $M$ on Tue, Apr. 18, 2000, 12:40

My mentor told me to remember two important C's-they are consistency and compassion. Consistency in your expectations from the students/what you expect from them. Compassion in that you care about them as individuals -it's not just a job.

Article No. 556: posted by $R$ on Sat, May. 20, 2000, 10:50

I have found that to be able to implement good behaviour management strategies, it is very important to provide a safe welcoming environment for the students.... When the students enter the room, there is a warm friendly feeling which is non-threatening for the students..

Article No. 614:posted by $K$ on Wed, May. 24, 2000, 19:07

I have come to the conclusion that one of the best methods of managing secondary behaviour is by "tactically ignoring" it... Sometimes, the best method to use to curb their behaviour is simply to ignore that they exist. Then they no longer have a reason to misbehave.

Article No. 679: posted by $H$ on Tue, May. 30, 2000, 12:28

Prac teaching is a great opportunity to practice different management strategies. While I have been teaching kindergarten, I have realised that you need an array of management strategies. With the younger students quickly losing their motivation and concentration to learn the teacher must be prepared to steer the students back on track...

Article No. 692: posted by $R Y$ on Tue, May. 30, 2000, 17:03

My prac session this year has helped me immensely to improve my strategies and techniques in order to gain classroom control. Being placed in one of the wildest classes in the school has also helped me to understand why children behave like this... such as the very 
clever, but extremely naughty children, and the children with no desire for learning at all.

Article No. 706: posted by Ko on Fri, Jun. 2, 2000, 00:51

My mentor teacher has also been encouraging me to use my teacher's voice. At first I felt too timid to be firm with and get cross at the students. But I have learnt that without using your teacher's voice, students will not respect and respond to you. If students do misbehave, I have found that it pays to 'act' very cross and displeased.

Other entries followed similar themes. In most cases students adjusted to the routine of the mentor teacher's class and often followed similar strategies. They were prepared to question these strategies and to look for alternatives from peers, suggested readings and university facilitators.

\section{DISCUSSION AND CONCLUSION}

The discussion space was an effective tool for the sharing of knowledge and experiences. Over time the entries demonstrated a growth in knowledge and understanding that appeared to lead to improved management in the classroom. Also the student entries fromlater in the session support the assertion that they developed greater understanding of strategies related to the management of safe, and productive learning environments.

One advantage of the discussion space is accessibility. Students could add entries at any time and at any place that had an Internet connection. It appeared that they liked the opportunity to share experiences and knowledge with peers and the collegial tone of the entries is an indicator of this. However, a word of caution needs to be ra ised. This group was experienced in using discussion spaces and had worked together in various problem-solving groups for more than a year. As a result their face-to-face discussion skills as well as their on-line skills were highly developed. Further, they were engaged in teaching experiences that were relevant to their current and future needs. Facilitators need to be aware that just adding a chat space to a subject is not enough. There needs to a process that helps student engage with each other and other participants. Also the chat space has to fulfill a purpose that is relevant to the needs of students.

However, there were some limitations as two students were reluctant to share knowledge on-line and they did not enjoy using the discussion space. This indicates that it is dangerous to assume that ALL students will find this means of learning effective and comfortable. Another limitation is the size of the group - 24 students generated over 950 entries and these were read and responded to.
The task is time consuming, taking 10 to 15 minutes per day. If the group were larger the task of responding would be too onerous.

At this stage we can confidently report that our experience with on-line discussion spaces to support a knowledge building community of beginning teachers has been mostly positive. Many of our colleagues have used this technology with mixed success and we speculate that they may have under-estimated the prior preparation need to turn the technology from an add-on to a useful learning tool.

\section{REFERENCES}

Bereiter, C. \& Scardamalia, M. (1993). Surpassing ourselves. Open Court. Illinois.

Besser, H. \& Bonn, M. (1996). Impact of distance independent education. Journal of the American Society of Information Science 47, 817-883.

Brown, J. S. \& Duguid, P. (1993) Stolen knowledge. Educational Technology. 33, 10-15.

Darling-Hammond, L. (1999).Teacher Education: Rethinking

Practice and Policy. Unicorn 25(1), 31-48.

Entwhistle, N., Entwhistle A., \& Tait H.(1993). Academic Understanding and the Contexts to Enhance It: A perspective from research on student learning In T.M. Duffy, J.Lowyck \& D.H. Jonassen (Eds.) Design Environments for Constructive Learning. Heidelberg: Springer-Verlag, 331-357.

Ferry, B., Kiggins, J., Hoban, G. \& Lockyer, L. (2000). Using computer-mediated-communication to form a knowledgebuilding community with beginning teachers. Educational Technology and Society, 3(3), 496-505.

Koetsier, C.P. \& Wubbels, J. T. (1995). Bridging the Gap Between Initial Teacher Training and Teacher Induction. Journal of Education for Teaching 21(3), 333-345.

Lave, J. \& Wenger, E. (1991). Situated learning: Legitimate peripheral participation. Cambridge: Cambridge University Press.

Lockyer, L., Patterson, J., \& Harper, B. (1999). Measuring effectiveness of health education in a Web-based learning environment: a preliminary report. Higher Education Research \& Development. 18(2), 233-246.

MACQT, (1998). Teacher preparation for student management: Responses and directions. Report by Ministerial Advisory Council on the Quality of Teaching, October, 1998. Sydney: NSW Department of Education and Training. Ramsey, G. (2000). Quality Matters: Revitalising teaching: critical times, critical choices. Report on the Review of Teacher Education, NSW. Sydney: Department of Education and Training.

Romiszowski, A. J., \& Mason, R. (1996). Computer-mediated communication. In D. H. Jonassen (Ed.), Handbook of Research for Educational Communications and Technology. (pp. 438-456). New York: Macmillian LIBRARY Reference USA.

Scardamalia, M. \&. Bereiter,C. (1996). Engaging Students in a Knowledge Society. Educational Leadership. 54 (3), 6-10 Weedman, J. (1998) Burgular's tools: the use of collaborative technology in professional socialisation. Paper presented at ASIS Midyear'98 Proceedings. Available at URL 